\title{
Оцінка якості життя пацієнтів із морбідним ожирінням піс.ля операції моноанастомозного шунтування шлунка в модифікації клініки
}

\begin{abstract}
Мета роботи: оцінити кореляцію якості життя та динаміку маси тіла пацієнтів із морбідним ожирінням після проведеної операції моноанастомозного шунтування шлунка в модифікації клініки і порівняти отримані результати з класичною методикою Roux-en-Y.

Матеріали і методи. Проведено аналіз найближчих і віддалених результатів лікування 31 пацієнта з морбідним ожирінням в період із 2011 до 2019 р., які були розподілені на 2 групи. Основну групу склали пацієнти, яким було виконано моноанастомозне шунтування шлунка в модифікації клініки - 20 осіб. Контрольну групу - пацієнти, які перенесли класичне Roux-en-Y шунтування шлунка - 11 осіб. Хворі були порівняні за основними показниками, при цьому жінок було 94,7 \% і 91 \%, середній вік становив $(39,42 \pm 2,58)$ року і $(37,36 \pm 3,65)$ року, зниження індексу маси тіла було на $33,9 \%$ і 38,2 \%, коморбідну патологію виявлено у 73,6 \% і 72,7 \% в основній групі і контрольній групі відповідно. Порівняльний аналіз оцінки якості життя був проведений до і після операції за системою “The Short Form-36”, питання в якому згруповані у 8 розділів, кожен із них оцінюється в балах від 0 до 100. Статистична обробка проведена пакетом Statistica 13. Нормальність розподілу даних перевірені критерієм Шапіро-Уїлка і залежно від цього критерій Стьюдента або критерій Манна-Уїтні були використані при порівнянні відмінностей між групами. Статистично значущим вважали $\mathrm{p}<0,05$. Для оцінювання зв’язку між показниками використовували коефіцієнт кореляції Спірмена.

Результати досліджень та їх обговорення. При порівняльній оцінці результатів якості життя обох типів операцій встановлено відсутність суттєвих відмінностей через 12 місяців після операції та виявлено кореляцію між зниженням індексу маси тіла та покращенням показників якості життя. Встановлено, що якість життя хворих із морбідним ожирінням обох груп достовірно не відрізняється. Порівнювальні показники достовірно не відрізняються за загальною сумою балів опитування та в окремих блоках питань. Доведена залежність між зниженням маси тіла та покращенням якості життя, покращується фізична активність при стійкому зниженні індексу маси тіла, покращується соціальне життя пацієнтів. Якість життя пацієнтів основної групи порівняна з якістю життя пацієнтів після класичного шунтування за Roux-en-Y.
\end{abstract}

Ключові слова: морбідне ожиріння; шунтування шлунка; якість життя; хірургічне лікування.

Постановка проблеми і аналіз останніх досліджень та публікацій. Дослідження проведено у рамках науково-дослідної роботи Запорізького державного медичного університету: “Хiрургічні (відкриті, лапароскопічні втручання) та ендоскопічні методи лікування захворювань органів черевної порожнини, стравоходу з розробкою і впровадженням нових способів та використанням ендосонографічних, ендоваскулярних технологій $з$ оцінкою якості життя” № держреєстрації 0117 U006964.

Морбідне ожиріння (МО) - значно поширена патологія у світі. За даними ВООЗ на МО страждають близько 13 \% населення планети. В Україні цей показник складає 24,1 \% [1]. Дані літератури вказують, що найбільш ефективним методом лікування морбідного ожиріння $є$ баріатрична операція, яка приводить до стабільної значної втрати ваги і позитивно впливає на супутні захворювання, пов'язані з ожирінням [2, 3]. Метою баріатричної хірургії є не тільки адекватне зниження маси тіла та усунення проявів метаболічного синдрому, але й поліпшення якості життя за оцінкою пацієнта [57] . На сьогодні розроблено декілька дієвих варіан- тів баріатричних операцій, але незважаючи на це, все ще не створено єдиного ідеального способу хірургічного лікування морбідного ожиріння [6].

Останнім часом набирає популярність лапароскопічне одноанастомозне шунтування шлунка [20, 21]. Вперше ця операція, також відома як minigastric bypass (MGB), була описана R. Rutledge y 1997 році [22]. За даними деяких авторів вона $\epsilon$ технічно більш простою і не менш ефективною, ніж класична методика Roux-en-Y gastric bypass (RYGB) $[8,9]$.

Зворотною стороною медалі $є$ те, що баріатрична операція може призвести до ряду післяопераційних ускладнень з можливими у поодиноких випадках тяжкими метаболічними порушеннями, демпінг-синдромом [12-14]. Методика MGB може бути асоційована з жовчним рефлюксом у стравохід і подальшим розвитком лужного рефлюкс-езофагіту, дисплазії та асоційованого з ним раку стравоходу, водночас MGB може бути використана у хворих із грижею стравохідного отвору діафрагми і надає позитивний ефект при гастро-езофагеальному рефлюксі, а також має доказову ефективність у хворих на цукровий діабет 2 типу [10, 11]. 
Значна кількість конкурентних методик оперативного лікування МО вказує на те, що жодна 3 них не відповідає сукупності основоположних принципів лікування, тобто має бути простою у виконанні $з$ мінімальним ризиком ускладнень та забезпечувати стабільно високу ефективність та якість життя для кожного пацієнта [15].

Ідучи шляхом удосконалення методики MGB, ми розробили, впровадили в практику і отримали патент на корисну модель № 141842 “Спосіб хірургічного лапароскопічного лікування морбідного ожиріння”. За даною методикою формується шлункова кукса завдовжки 6 см та 2,5 см у діаметрі з ручним антирефлюксним гастроентероанастомозом кінець у бік на 2 м від зв'язки Трейца. Дана методика дає можливісь ефективно знизити надлишкову масу та позитивно впливає на супутні захворювання.

Результати баріатричних операцій вимагають детальної оцінки й одним з основних критеріїв $€$ вивчення рівня якості життя після операційного лікування. Розроблена методика так само вимагає оцінки не тільки динаміки зниження маси пацієнта і плину супутніх захворювань, а й оцінки якості життя, наявності жовчного рефлюксу, езофагіту. Суб’єктивна оцінка якості життя може надати цінну інформацію про ефективність проведеного лікування [17]. Однією з найбільш інформативних для визначення якості життя $є$ анкета Short Form 36 (SF-36), яка має найбільш широке використання і універсальні характеристики для оцінки результатів лікування $[16,18,19]$.

Мета роботи: оцінка кореляції якості життя та динаміки маси тіла пацієнтів із морбідним ожирінням після проведеної операції моноанастомозного шунтування шлунка в нашій модифікації та порівняння отриманих результатів із класичною методикою Roux-en-Y.

Матеріали і методи. Вивчено найближчі й віддалені результати лікування 31 пацієнта з морбідним ожирінням, які перенесли шунтувальні операції. Пацієнти були розділені на дві групи. Модифіковане в клініці лапароскопічне моноанастомозне шунтування шлунка (ЛМШШ) було виконано 20 хворим (основна група). 11 хворих після стандартної методики лапароскопічного шунтування шлунка за Roux-en-Y склали контрольну групу. Хворі були прооперовані у період з 2011 до 2019 р. та були порівняні за основними показниками (індекс маси тіла, наявність коморбідної патології, стать та вік). В основній групі жінок було 18 (94,7 \%), чоловіків - 1 (5,3 \%). У контрольній групі жінок було 10 (91,0 \%), чоловіків - 1 (9,0 \%). Середній вік склав $(39,42 \pm 2,58)$ року в основній гру- пі і $(37,36 \pm 3,65)$ року в групі контролю (p>0,05). Маса тіла пацієнтів становила від 90 до 173 кг. Середній IMT в основній групі до операції був $42,7 \mathrm{\kappa г} / \mathrm{M}^{3}$, а через 12 місяців після операції став 27,6 (зменшення на 33,9 \%). Середній IMT у контрольній групі до операції був 42,4, а через 12 місяців після операції став 26,0 (зменшення на 38,2 \%).

Коморбідну патологію виявлено у 73,6 \% (у 31,5 \% із них - поєднанні захворювання) основної групи і 72,7 \% (у 27,2 \% з них - поєднані захворювання) контрольної групи, при цьому всі пацієнти з IMT нижче 40 мали прояви метаболічного синдрому та синдрому сонного апное.

Усіх хворих обстежували до операції, а також у термін 3, 6 і 12 місяців після операції і далі щороку. Виконували стандартні клініко-біохімічні обстеження, ліпідограму, досліджували С-пептид, інсулін, індекс НОМА, лептин. Також виконували рентгеноскопію верхнього відділу шлунковокишкового тракту з барієм, езофагогастродуоденоскопію з біопсією слизової оболонки стравоходу і кукси шлунка для виключення дисплазії, добова $\mathrm{pH}$-імпедансометрія, УЗД органів черевної порожнини.

Для визначення якості життя використовували опитувальник Short Form 36 (SF-36). Питання в анкеті SF-36 групуються в 8 розділів: фізична активність, рольова діяльність, виразність больового синдрому, загальне здоров’я, життєздатність, соціальний статус, емоційний статус, психічне здоров'я. Кожен із них оцінюється в балах від 0 до 100 [18].

1. Фізичне функціонування - Physical Functiong (PF) - шкала, яка оцінює фізичну активність, що включає самообслуговування, піднімання сходами, перенесення ваги, а також виконання значних фізичних навантажень. Показник шкали відображає обсяг повсякденного фізичного навантаження, який не обмежений станом здоров'я: чим він вищий, тим вище фізичне навантаження, на думку досліджуваного, він може виконати. Низькі показники за цією шкалою свідчать про те, що фізична активність значно обмежена станом здоров'я.

2. Рольове фізичне функціонування - Role Physical (RP) - шкала, яка показує роль фізичних проблем в обмеженні життедіяльності, відображає ступінь, в якому здоров'я лімітує виконання звичайної діяльності та повсякденних обов'язків тими проблемами, які пов'язані зі здоров'ям. Низькі показники за цією шкалою свідчать про те, що повсякденна діяльність значно обмежена фізичним станом здоров’я.

3. Шкала болю - Bodily Pain (ВР) - оцінює інтенсивність больового синдрому та його вплив на здатність займатися нормальною діяльністю, 
включно роботу вдома і поза ним впродовж останнього місяця: чим вище показник, тим менше, за думку респондента або пацієнта, больових відчуттів вони відчували. Низькі значення шкали свідчать про те, що біль значно обмежує фізичну активність досліджуваних.

4. Загальний стан здоров'я - General Health (GH) - оцінює стан здоров’я на даний момент, перспективи лікування й опірність хвороби: чим вище показник, тим кращий стан здоров'я респондента або пацієнта.

5. Шкала життєздатності - Vitality (VT) - має на увазі оцінку відчуття респондентом або пацієнтом повними сил і енергї. Низькі бали свідчать про стомленість досліджуваних, зниження їх життєвої активності.

6. Шкала соціального функціонування - Social Functioning (SF) - оцінює задоволеність рівнем соціальної активності (спілкуванням, проведенням часу з друзями, родиною) і відображає ступінь, в якій фізичний або емоційний стан пацієнта їх обмежує: чим вищий показник, тим вища соціальна активність за останні 4 тижні. Низькі бали відповідають значному обмеженню соціальних контактів, зниженню рівня спілкування внаслідок погіршення здоров’я.

7. Рольове емоційне функціонування - Role Emotional (RE) - передбачає оцінку ступеня, в якій емоційний стан заважає виконанню роботи або іншої звичайної повсякденної діяльності, включно великі затрати часу на їхнє виконання, зменшення обсягу зробленої роботи, зниження її якості: чим вище показник, тим менше емоційний стан обмежує повсякденну активність пацієнта.

8. Психологічне здоров'я - Mental Health (MH) - характеризує настрій, наявність депресії, тривоги, оцінює загальний показник позитивних емо- цій: чим вищий показник, тим більше часу пацієнти почували себе спокійними впродовж останнього місяця. Низькі показники свідчили про наявність депресивних, тривожних станів.

Статистичну обробку проводили за допомогою спеціалізованого пакета Statistica 13, ліцензія JPZ804I382130ARCN10-J. Дані перевіряли на нормальність розподілу за допомогою критерію Шапіро-Уїлка. Дані, розподілені за нормальним законом, представляли у формі середнє \pm середньоквадратичне відхилення (M $\pm \mathrm{SD})$, при відхиленні закону розподілу від нормального використовувалася форма подання у вигляді медіани і міжквартильного розмаху Ме (Q25; Q75). Відмінності між групою дослідження та групою порівняння проводили за допомогою критерію Стьюдента для незалежних вибірок при нормальному законі розподілу, при відхиленні закону розподілу від нормального використовували критерій Манна-Уїтні. Відмінності вважали статистично значущими при $\mathrm{p}<0,05$. Для оцінювання зв'язку між показниками використовували коефіцієнт кореляції Спірмена.

Результати досліджень та їх обговорення. Оцінку результатів хірургічного лікування хворих на морбідне ожиріння не можна давати тільки оцінюючи динаміку зниження маси тіла. Рівень якості життя пацієнтів до та після хірургічного лікування є важливим показником ефективності хірургічного лікування цієї категорії хворих. На підставі проведеного аналізу ми визначили, що рівень якості життя обох груп пацієнтів із морбідним ожирінням після операції достовірно вище, ніж до операційного лікування.

Показники рівня якості життя до операції пацієнтів із морбідним ожирінням за даними анкети SF-36 представлено в таблиці 1.

Таблиця 1. Якість життя хворих на морбідне ожиріння до операції за даними анкети SF-36

\begin{tabular}{||l|c|c||}
\hline \multicolumn{1}{|c|}{ Найменування розділів } & Група Roux-en-Y, n=11 & Група ЛМШШ, n=20 \\
\hline Фізична активність & $35(25 ; 45)$ & $35(20 ; 45)$ \\
\hline Рольова діяльність & $40(35 ; 50)$ & $40(28 ; 50)$ \\
\hline Больовий синдром & $60(45 ; 100)$ & $74(59 ; 80)$ \\
\hline Загальний стан здоров’я & $37(27 ; 45)$ & $31(20 ; 42)$ \\
\hline Життєздатність & $35(25 ; 45)$ & $52(30 ; 70)$ \\
\hline Соціальний статус & $55(50 ; 63)$ & $43(33 ; 67)$ \\
\hline Емоційний статус & $35(33 ; 46)$ & $28(15 ; 40)$ \\
\hline Психологічне здоров’я* & $44(36 ; 52)$ & \\
\hline \hline
\end{tabular}

Примітка. *- статистично значуща різниця між групами $(\mathrm{p}<0,05)$. 
3 наведених даних випливає, що достовірних відмінностей у двох групах за всіма блоками питань, крім психологічного здоров’я, не виявлено, що вказує на подібність рівня якості життя пацієнтів до операції.

Такі показники зумовлені тим, що групи пацієнтів були порівняльні за середнім IMT, середнім віком, коморбідною патологією.

Показники рівня якості життя після операції пацієнтів обох груп представлено в таблиці 2.

3 наведених даних можна зробити висновок, що достовірних відмінностей в обох групах за всіма блоками питань не виявлено, що також вказує на подібність рівня якості життя пацієнтів після операції.
Після операції спостерігається тенденція зростання усіх показників як в групі хворих, які перенесли шунтування шлунка за класичною методикою Roux-en-Y, так і в групі хворих після ЛМШШ. Показники якості життя в обох групах оперованих хворих практично однакові і не залежать від проведеного операційного втручання.

Для визначення взаємозалежності зміни показників рівня якості життя після операції з показниками, які характеризують відносне зменшення маси тіла та отриманий індекс маси тіла, ми визначили коефіцієнти кореляції цих показників (табл. 3).

Тільки за трьома показниками виявлено достовірну кореляцію покращення якості життя 3 відносним зниженням маси тіла та з отриманим

Таблиця 2. Якість життя хворих на морбідне ожиріння після операції за даними анкети SF-36

\begin{tabular}{|c|c|c|}
\hline Найменування розділів & Група Roux-en-Y, n=11 & Група ЛМшш, n= 20 \\
\hline Фізична активність & $85(80 ; 90)$ & $90(85 ; 90)$ \\
\hline Рольова діяльність & $100(75 ; 100)$ & $100(75 ; 100)$ \\
\hline Больовий синдром & $100(100 ; 100)$ & $100(100 ; 100)$ \\
\hline Загальний стан здоров’я & $80(70 ; 85)$ & $69(64 ; 81)$ \\
\hline Життєздатність & $80(70 ; 85)$ & $75(70 ; 80)$ \\
\hline Соціальний статус & $88(88 ; 100)$ & $88(88 ; 100)$ \\
\hline Емоційний статус & $100(67 ; 100)$ & $100(67 ; 100)$ \\
\hline Психологічне здоров’я & $72(60 ; 80)$ & $72(62 ; 80)$ \\
\hline
\end{tabular}

Таблиця 3. Коефріцієнти кореляції між зміною показників шкали SF-36 та співвідношенням втраченої маси до зросту пацієнтів та індексом маси тіла через 12 місяців після операції

\begin{tabular}{||l|c|c||}
\hline \multirow{2}{*}{$\begin{array}{c}\text { Показники якості } \\
\text { життя }\end{array}$} & \multicolumn{2}{|c||}{ Коефіцієнт кореляції } \\
\cline { 2 - 3 } & відношення втраченої маси тіла до зросту пацієнтів & отриманий індекс маси тіла \\
\hline Фізична активність* & 0,51 & 0,48 \\
\hline Рольова діяльність & 0,10 & 0,04 \\
\hline Больовий синдром* & 0,39 & 0,41 \\
\hline Загальне здоров’я & 0,28 & 0,24 \\
\hline Життєздатність & 0,34 & 0,30 \\
\hline Соціальний статус* & 0,43 & 0,43 \\
\hline Емоційний статус & $-0,01$ & $-0,02$ \\
\hline Психічне здоров’я & 0,21 & 0,22 \\
\hline \hline
\end{tabular}

Примітка. Знаком * позначено показники, для яких значення коефіцієнта кореляції є статистично значущим (p<0,05). 
індексом маси тіла пацієнтів: больовий синдром, соціальний статус і фізична активність, всі зв'язки прямі, середньої сили.

Встановлено, що ступінь зниження індексу маси тіла у основній групі 33,9 \% за 12 місяців і у контрольній групі 38,2 \%. Різниця зниження індексу маси тіла між двома групами склала 4,3 \%. Ми можемо розцінювати такі результати як порівнювані, як за покращенням показників якості життя, так і за динамікою зниження індексу маси тіла в обох групах, при цьому достовірної різниці за цими показниками до операції теж не виявлено.

За результатами проведених досліджень встановлено зниження якості життя у хворих із морбідним ожирінням. Після операційного лікування спостерігається зростання цих показників в обох групах.

Можна зазначити, що показники якості життя після операції в обох групах практично однакові і не залежать від проведеного операційного втручання. При цьому ступінь зниження індексу маси тіла після операції в модифікації клініки (основна група) - 33,9 \%, а у групі Roux-en-Y (контрольна) - на $38,2 \%$, що є статистично недостовірною різницею.

При аналізі анкети з вивчення якості життя виявлено, що ця анкета переконливо доводить, що якість життя хворих із морбідним ожирінням обох груп достовірно не відрізняється. При цьому дані показники не відрізняються як за загальною сумою балів, так і в окремих блоках питань. Якість життя пацієнтів, яким виконане модифіковане моноанастомозне лапароскопічне шунтування шлунка, порівняна з якістю життя пацієнтів після класичного шунтування Roux-en-Y.

За допомогою опитувальника SF 36 доведено залежність між зниженням маси тіла та покращенням якості життя, а саме: покращується фізична активність за рахунок ефективного та стійкого зниження індексу маси тіла, при цьому покращується соціальне життя пацієнтів. Зв’язок зі зменшенням болю пояснюється наявністю супутніх захворювань опорно-рухового апарату та позитивною динамікою при зменшенні ваги пацієнтів.

Вивчення кореляції між індексом маси тіла і показниками якості життя продемонструвало, що за даними анкети SF-36 є пряма залежність між показниками фізичного благополуччя і зменшенням відношення втраченої маси до зросту пацієнтів, тобто чим нижча маса тіла, тим вище фізичне благополуччя та соціальне функціонування.

Також потребують дослідження динаміка супутніх захворювань та визначення наявності біліарного рефлюксу до сформованого шлунка та стравоходу.
Аналіз даних та результати робіт авторів, які проводили аналіз якості життя після баріатричних операцій, дали можливість отримати дані про подібні результати.

Dymek та ін. [23] виявили існування суттєвих відмінностей якості життя серед пацієнтів до та після операції RYGB. Симптоми депресії та самооцінка помітно покращились, особливо в перший рік після RYGB. Використовуючи опитувальники SF-36 та IWQOL-Lite у післяопераційному періоді, спостерігалося значне поліпшення стану фізичного та психічного здоров'я, яке поступово зростало [23].

Chang та ін. [24] повідомили, що поліпшення були зареєстровані в різних областях і аспектах якості життя впродовж перших 3 місяців, після чого спостерігалася невелика тенденція до зниження фізичного та психологічного аспекту між 3 i 6 місяцями, які, найвірогідніше, були пов'язані з післяопераційними ускладненнями, а потім спостерігалося подальше поліпшення до кінця першого року. Їх дослідження показало, що лапароскопічне шунтування шлунка може поліпшити як фізичне, так і психічне здоров'я SF-36 [24, 25].

У своєму порівняльному дослідженні з використанням індексу (GIQLI) для оцінки якості життя після лапароскопічних MGB та RYGB, Lee та ін. [26] повідомили, що показники GIQLI після MGB були значно вищі, ніж доопераційні. У цьому дослідженні не виявлено значної різниці між результатами після RYGB і MGB. Автори дійшли висновку, що MGB - ефективна баріатрична операція, яка значно покращує якість життя і має перевагу у тому, що вона простіша, з меншими витратами та необхідністю ревізійної операції в порівнянні з RYGB.

За даними міжнародної літератури доведено, що баріатрична хірургія сприяє значному покращенню якості життя після операції порівняно 3 іншими методами схуднення [27, 28]. Шлункове шунтування $\epsilon$ загальноприйнятим та ефективним методом боротьби не лише з ожирінням, а й зі зменшенням або усуненням супутніх захворювань. Ці переваги можуть поліпшити якість життя людини, покращити функціональні можливості [29].

Висновки. 1. Хворі на морбідне ожиріння мають знижену якість життя за даними опитувальника SF 36. 2. У хворих на морбідне ожиріння проведення баріатричної операції приводить до статистично значущого збільшення показників якості життя.

3. Рівень якості життя хворих на ожиріння контрольної і основної групи достовірно не від- 
різняється, що свідчить про ефективність модифікованої в клініці методики лапароскопічного моноанастомозного шунтування шлунка та порівнянність її зі стандартною методикою Roux-en-Y.
4. За даними анкет SF-36, є пряма, середньої сили кореляція між індексом маси тіла та якістю життя пацієнтів за напрямами больовий синдром, соціальний статус і фізична активність.

\section{СПИСОК ЛІТЕРАТУРИ}

1. Obesity [Electronic resource]. - URL: https://www.who.int/ news-room/fact-sheets/detail/obesity-and- overweight

2. Bariatric surgery / H. Buchwald, Y. Avidor, E. Braunwald [et al.] // JAMA. - 2004. - No. 292 (14). - P. 1724.

3. Sjöström L. Effects of bariatric surgery on mortality in Swedish obese subjects / L. Sjöström, K. Narbro, C. Sjöström [et al.] // New England Journal of Medicine. - 2007. - No. 357 (8). P. 741-752.

4. Jennings N. A. Procedure selection in bariatric surgery. In: Agrawal S. Obesity, Bariatric and Metabolic Surgery / N. A. Jennings, P. K. Small. - Switzerland: Springer International Publishing. - 2016. - P. 85-89.

5. The impact of bariatric surgery on quality of life: a systematic review and meta-analysis/ N. Lindekilde, B. Gladstone, M. Lübeck [et al.] // Obesity Reviews. - 2015. - No. 16 (8). - P. 639-651.

6. Sarwer D. quality of life, body image and sexual functioning in bariatric surgery patients / D. Sarwer, K. Steffen // European Eating Disorders Review. - 2015. - No. 23 (6). - P. 504-508.

7. Impact of weight change on quality of life in adults with overweight/obesity in the United States: a systematic review / M. Kroes, G. Osei-Assibey, R. Baker-Searle [et al.] // Current Medical Research and Opinion. - 2016. - No. 32 (3). - P. 485-508.

8. Complications following the mini/one anastomosis gastric bypass (MGB/OAGB): a multi-institutional survey on 2678 patients with a mid-term (5 years) follow-up/ M. Musella, A. Susa, E. Manno [et al.] // Obesity Surgery. - 2017. - No. 27 (11). P. 2956-2967.

9. Jammu G. A 7-year clinical audit of 1107 cases comparing sleeve gastrectomy, Roux-En-Y gastric bypass, and mini-gastric bypass, to determine an effective and safe bariatric and metabolic procedure / G. Jammu, R. Sharma // Obesity Surgery. - 2015. - No. 26 (5). - P. 926-932.

10. Tolone S. Effects of omega-loop bypass on esophagogastric junction function / S. Tolone, S. Cristiano, E. Savarino [et al.] // Surgery for Obesity and Related Diseases. - 2016. - No. 12 (1). - P. 62-69.

11. Mion F. High-resolution impedance manometry after sleeve gastrectomy: increased intragastric pressure and reflux are frequent events / F. Mion, S. Tolone, A. Garros [et al.] // Obesity Surgery. - 2016. - No. 26 (10). - P. 2449-2456.

12. Puzziferri N. Long-term follow-up after bariatric surgery / N. Puzziferri, T. Roshek, H. Mayo [et al.] // JAMA. - 2014. No. 312 (9). - P. 934.

13. Ramanan B. Development and validation of a bariatric surgery mortality risk calculator/ B. Ramanan, P. K. Gupta, H. Gupta [et al.] // Journal of the American College of Surgeons. - 2012. - No. 214 (6). - P. 892-900.

14. Bariatric surgery: a systematic review and meta-analysis / H. Buchwald, Y. Avidor, E. Braunwald [et al.] // JAMA. - 2004. - No. 292 (14). - P. 1724-1737.

15. Rutledge R. Continued excellent results with the mini-gastric bypass: six-year study in 2,410 patients / R. Rutledge, T. R. Walsh // Obesity Surgery. - 2005. - No. 15 (9). - P. 1304-1308.

16. Patient-reported outcomes in bariatric surgery: a systematic review of standards of reporting / K. D. Coulman, T. Abdelrahman, A. Owen-Smith [et al.] // Obesity Reviews: An Official Journal of the International Association for the Study of Obesity. 2013. - No. 14 (9). - P. 707-720.

17. Weldring T. Patient-reported outcomes (PROs) and patientreported outcome measures (PROMs) / T. Weldring, S. M. Smith // Health Services Insights. - 2013. - No. 6. - P. 61-68.

18. The MOS 36-item Short-Form Health Survey (SF-36): III. Tests of data quality, scaling assumptions, and reliability across diverse patient groups / C. A. McHorney, J. E. Ware, J. F. Jr Lu [et al.] // Medical Care. - 1994. - No. 32 (1). - P. 40-66.

19. Characteristics of adolescents with poor mental health after bariatric surgery/ K. Järvholm, J. Karlsson, T. Olbers [et al.] // Surgery for Obesity and Related Diseases: Official Journal of the American Society for Bariatric Surgery. - 2016. - No. 12 (4). P. 882-890.

20. 20th IFSO World Congress // Obesity Surgery. - 2015. No. 25 (S1). - P. 1-364.

21. One-anastomosis gastric bypass as an alternative procedure of choice in morbidly obese patients / A. Solouki, M. Kermansaravi, A. H. Davarpanah Jazi[et al.] // Journal of Research in Medical Sciences: The Official Journal of Isfahan University of Medical Sciences. - 2018. - No. 23. - P. 84.

22. Rutledge R. The mini-gastric bypass: experience with the first 1,274 cases / R. Rutledge // Obesity Surgery. - 2001. - No. 11 (3). - P. 276-280.

23. Quality of life after gastric bypass surgery: a cross-sectional study / M. P. Dymek, D. Le Grange, K. Neven, J. Alverdy // Obesity Research. - 2002. - No. 10 (11). - P. 1135-1142.

24. Prospective study of health-related quality of life after Rouxen-Y bypass surgery for morbid obesity / C. Chang, C. Huang, Y. Chang [et al.] // British Journal of Surgery. - 2010. - No. 97 (10). - P. 1541-1546.

25. Laparoscopic versus open gastric bypass: a randomized study of outcomes, quality of life, and costs / N. T. Nguyen, C. Goldman, C. J. Rosenquist [et al.] // Annals of Surgery. - 2001. No. 234 (3). - P. 279-291.

26. Laparoscopic Roux-en-Y vs. mini-gastric bypass for the treatment of morbid obesity: a 10-year experience / W. J. Lee, K. H. Ser, Y. C. Lee [et al.] // Obesity Surgery. - 2012. - No. 22 (12). - P. 1827-1834.

27. Karlsson J. Ten-year trends in health-related quality of life after surgical and conventional treatment for severe obesity: the SOS intervention study / J. Karlsson, C. Taft, A. Rydén [et al.] // International Journal of Obesity. - 2007. - No. 31 (8). - P. 12481261.

28. Canetti L. Health-related quality of life changes and weight reduction after bariatric surgery vs. a weight-loss program / L. Canetti, Y. Elizur, Y. Karni [et al.] // The Israel Journal of Psychiatry and Related Sciences. - 2013. - No. 50 (3). - P. 194-200.

29. Changes in functional walking distance and health-related quality of life after gastric bypass surgery / J. Tompkins, P. R. Bosch, R. Chenowith [et al.] // Physical Therapy. - 2008. No. 88 (8). - P. 928-935. 


\section{REFERENCES}

1. (2021). Obesity. Retrieved 31 March 2021, from https://www. who.int/news-room/fact-sheets/detail/obesity-and-overweight 2. Buchwald, H., Avidor, Y., Braunwald, E., Jensen, M., Pories, W., Fahrbach, K., \& Schoelles, K. (2004). Bariatric Surgery. JAMA, 292 (14), 1724. DOI: 10.1001/jama.292.14.1724

3. Sjöström, L., Narbro, K., Sjöström, C., Karason, K., Larsson, B., \& Wedel, H. et al. (2007). Effects of bariatric surgery on mortality in Swedish obese subjects. New England Journal of Medicine, 357 (8), 741-752. DOI: 10.1056/nejmoa066254

4. Jennings, N.A., \& Small, P.K. (2016). Procedure selection in bariatric surgery. Agrawal, S. (Ed.). Obesity, Bariatric and Metabolic Surgery (pp. 85-89). Switzerland: Springer International Publishing.

5. Lindekilde, N., Gladstone, B., Lübeck, M., Nielsen, J., Clausen, L., Vach, W., \& Jones, A. (2015). The impact of bariatric surgery on quality of life: a systematic review and meta-analysis. Obesity Reviews, 16 (8), 639-651. DOI: 10.1111/obr.12294

6. Sarwer, D., \& Steffen, K. (2015). Quality of life, body image and sexual functioning in bariatric surgery patients. European Eating Disorders Review, 23 (6), 504-508. DOI: 10.1002/erv.2412

7. Kroes, M., Osei-Assibey, G., Baker-Searle, R., \& Huang, J. (2016). Impact of weight change on quality of life in adults with overweight/obesity in the United States: a systematic review. Current Medical Research and Opinion, 32 (3), 485-508. DOI: 10.1185/03007995.2015.1128403

8. Musella, M., Susa, A., Manno, E., De Luca, M., Greco, F., \& Raffaelli, M. et al. (2017). Complications following the mini/ one anastomosis gastric bypass (MGB/OAGB): a multi-institutional survey on 2678 patients with a mid-term (5 years) followup. Obesity Surgery, 27 (11), 2956-2967. DOI: 10.1007/s11695017-2726-2

9. Jammu, G., \& Sharma, R. (2015). A 7-year clinical audit of 1107 cases comparing sleeve gastrectomy, Roux-En-Y gastric bypass, and mini-gastric bypass, to determine an effective and safe bariatric and metabolic procedure. Obesity Surgery, 26 (5), 926932. DOI: 10.1007/s11695-015-1869-2

10. Tolone, S., Cristiano, S., Savarino, E., Lucido, F., Fico, D., \& Docimo, L. (2016). Effects of omega-loop bypass on esophagogastric junction function. Surgery for Obesity and Related Diseases, 12 (1), 62-69. DOI: 10.1016/j.soard.2015.03.011

11. Mion, F., Tolone, S., Garros, A., Savarino, E., Pelascini, E., \& Robert, M. et al. (2016). High-resolution impedance manometry after sleeve gastrectomy: increased intragastric pressure and reflux are frequent events. Obesity Surgery, 26 (10), 2449-2456. DOI: 10.1007/s11695-016-2127-y

12. Puzziferri, N., Roshek, T., Mayo, H., Gallagher, R., Belle, S., \& Livingston, E. (2014). Long-term follow-up after bariatric surgery. JAMA, 312 (9), 934. DOI: 10.1001/jama.2014.10706

13. Ramanan, B., Gupta, P. K., Gupta, H., Fang, X., \& Forse, R. A. (2012). Development and validation of a bariatric surgery mortality risk calculator. Journal of the American College of Surgeons, 214 (6), 892-900. DOI: 10.1016/j.jamcollsurg.2012.02.011

14. Buchwald, H., Avidor, Y., Braunwald, E., Jensen, M.D., Pories, W., Fahrbach, K., \& Schoelles, K. (2004). Bariatric surgery: a systematic review and meta-analysis. JAMA, 292 (14), 17241737. DOI: 10.1001/jama.292.14.1724

15. Rutledge, R., \& Walsh, T.R. (2005). Continued excellent results with the mini-gastric bypass: six-year study in 2,410 patients. Obesity Surgery, 15 (9), 1304-1308. DOI: $10.1381 / 096089205774512663$

16. Coulman, K.D., Abdelrahman, T., Owen-Smith, A., An- drews, R.C., Welbourn, R., \& Blazeby, J.M. (2013). Patient-reported outcomes in bariatric surgery: a systematic review of standards of reporting. Obesity reviews: An Official Journal of the International Association for the Study of Obesity, 14 (9), 707-720. DOI: 10.1111/obr.12041

17. Weldring, T., \& Smith, S.M. (2013). Patient-reported outcomes (PROs) and patient-reported outcome measures (PROMs). Health Services Insights, 6, 61-68. DOI: 10.4137/HSI.S11093 18. McHorney, C.A., Ware, J.E., Jr, Lu, J.F., \& Sherbourne, C.D. (1994). The MOS 36-item Short-Form Health Survey (SF36): III. Tests of data quality, scaling assumptions, and reliability across diverse patient groups. Medical Care, 32 (1), 40-66. DOI: 10.1097/00005650-199401000-00004

19. Järvholm, K., Karlsson, J., Olbers, T., Peltonen, M., Marcus, C., Dahlgren, J., Gronowitz, E., Johnsson, P., \& Flodmark, C.E. (2016). Characteristics of adolescents with poor mental health after bariatric surgery. Surgery for Obesity and Related Diseases: Official Journal of the American Society for Bariatric Surgery, 12 (4), 882-890. DOI: 10.1016/j.soard.2016.02.001 20. 20th IFSO World Congress. (2015). Obesity Surgery, 25 (S1), 1-364. DOI: 10.1007/s11695-015-1750-3

21. Solouki, A., Kermansaravi, M., Davarpanah Jazi, A.H., Kabir, A., Farsani, T. M., \& Pazouki, A. (2018). One-anastomosis gastric bypass as an alternative procedure of choice in morbidly obese patients. Journal of Research in Medical Sciences: The Official Journal of Isfahan University of Medical Sciences, 23, 84. DOI: 10.4103/jrms.JRMS_386_18

22. Rutledge R. (2001). The mini-gastric bypass: experience with the first 1,274 cases. Obesity Surgery, 11 (3), 276-280. DOI: $10.1381 / 096089201321336584$

23. Dymek, M.P., Le Grange, D., Neven, K., \& Alverdy, J. (2002). Quality of life after gastric bypass surgery: a cross-sectional study. Obesity Research, 10 (11), 1135-1142. DOI: 10.1038/ oby. 2002.154

24. Chang, C., Huang, C., Chang, Y., Tai, C., Lin, J., \& Wang, J. (2010). Prospective study of health-related quality of life after Roux-en-Y bypass surgery for morbid obesity. British Journal of Surgery, 97 (10), 1541-1546. DOI: 10.1002/bjs.7179

25. Nguyen, N. T., Goldman, C., Rosenquist, C. J., Arango, A., Cole, C. J., Lee, S. J., \& Wolfe, B.M. (2001). Laparoscopic versus open gastric bypass: a randomized study of outcomes, quality of life, and costs. Annals of Surgery, 234 (3), 279-291. DOI: 10.1097/00000658-200109000-00002

26. Lee, W.J., Ser, K.H., Lee, Y.C., Tsou, J.J., Chen, S.C., \& Chen, J.C. (2012). Laparoscopic Roux-en-Y vs. mini-gastric bypass for the treatment of morbid obesity: a 10-year experience. Obesity Surgery, 22 (12), 1827-1834. DOI: 10.1007/s11695-0120726-9

27. Karlsson, J., Taft, C., Rydén, A., Sjöström, L., \& Sullivan, M. (2007). Ten-year trends in health-related quality of life after surgical and conventional treatment for severe obesity: the SOS intervention study. International Journal of Obesity, 31 (8), 12481261. DOI: $10.1038 /$ sj.ijo.0803573

28. Canetti, L., Elizur, Y., Karni, Y., \& Berry, E.M. (2013). Health-related quality of life changes and weight reduction after bariatric surgery vs. a weight-loss program. The Israel Journal of Psychiatry and Related Sciences, 50 (3), 194-200.

29. Tompkins, J., Bosch, P.R., Chenowith, R., Tiede, J.L., \& Swain, J.M. (2008). Changes in functional walking distance and health-related quality of life after gastric bypass surgery. Physical Therapy, 88 (8), 928-935. DOI: 10.2522/ptj.20070296 


\title{
QUALITY OF LIFE ASSESSMENT IN PATIENTS WITH MORBID OBESITY AFTER SINGLE ANASTOMOSIS GASTRIC BYPASS OPERATION IN THE MODIFICATION OF THE CLINIC
}

\begin{abstract}
The aim of the work: to assess the correlation between the quality of life and the dynamics of body weight in patients with morbid obesity after the monoanastomotic gastric bypass operation in the modification of the clinic and to compare the obtained results with the classical Roux-en-Y technique.

Materials and Methods. We performed the analysis of the immediate and long-term results of treatment of 31 patients with morbid obesity in the period from 2011 to 2019, who were divided into 2 groups. The main group consisted of patients who underwent monoanastomotic gastric bypass surgery in the modification of the clinic - 20 patients. The control group - patients who underwent classical Roux-en-Y gastric bypass surgery - 11 patients. The patients were compared according to the main indicators, while women were $94.7 \%$ and $91 \%$, the average age was (39.42 \pm 2.58$)$ years and (37.36 \pm 3.65$)$ years, the decrease in body mass index was $33.9 \%$ and $38.2 \%$, comorbid pathology was found in $73.6 \%$ and $72.7 \%$ in the main group and the control group, respectively. A comparative analysis of the assessment of the quality of life was carried out before and after the operation using The Short Form-36 system, where the questions are grouped into 8 sections, each of which is evaluated in points from 0 to 100 . Statistical calculations were carried out using the Statistica 13. Normality of data distribution was tested by the Shapiro-Wilk test and, depending on this, the Student's test or the Mann-Whitney test were used for comparing the differences between groups. $\mathrm{P}<0.05$ was considered statistically significant. Spearman's correlation coefficient was used to assess association between the variables.

Results and Discussion. In a comparative assessment of the quality of life results of both types of operations, it was noticed that there were no significant differences 12 months after the operation, and a correlation was found between a decrease in body mass index and an improvement in quality of life indicators. It was found that the quality of life of patients with morbid obesity did not differ significantly in both groups. Comparative indicators do not significantly differ in the total score of the survey and in individual blocks of questions. It was proven, that there is a direct relationship between a decrease in body weight and an improvement in the quality of life; steady decrease in body mass index improves physical activity and the social life of patients. The quality of life of patients in the main group is comparable to the quality of life of patients after classic Roux-en-Y bypass surgery.
\end{abstract}

Key words: morbid obesity; gastric bypass; quality of life; surgery.

\section{А. В. КЛИМЕНКО, В. Н. КЛИМЕНКО, М. В. НИКОЛАЕВ}

Запорожский государственный медицинский университет

\section{ОЦЕНКА КАЧЕСТВА ЖИЗНИ ПАЦИЕНТОВ С МОРБИДНЫМ ОЖИРЕНИЕМ ПОС.Л ОПЕРАЦИИ МОНОАНАСТОМОЗНОГО ШУНТИРОВАНИЯ ЖЕЛУДКА В МОДИФИКАЦИИ КЛИНИКИ}

\begin{abstract}
Цель работы: оценить корреляцию качества жизни и динамику массы тела пациентов с морбидным ожирением после проведенной операции моноанастомозного шунтирования желудка в модификации клиники и сравнить полученные результаты с классической методикой Roux-en-Y.

Материалы и методы. Проведен анализ ближайших и отдаленных результатов лечения 31 пациента с морбидным ожирением в период с 2011 по 2019 г., которые были разделены на 2 группы. Основную группу составили пациенты, которым было выполнено моноанастомозное шунтирование желудка в модификации клиники - 20 человек. Контрольную группу - пациенты, перенесшие классическое Roux-en-Y шунтирование желудка - 11 человек. Было проведено сравнение больных по основным показателям, при этом женщин было 94,7 \% и 91 \%, средний возраст был $(39,42 \pm 2,58)$ лет и $(37,36 \pm 3,65)$ лет, снижение индекса массы тела было на 33,9 \% и 38,2 \%, коморбидной патологии обнаружено в 73,6 \% и 72,7 \% в основной группе и контрольной группе соответственно. Сравнительный анализ оценки качества жизни был проведен до и после операции по системе “The Short Form-36”, вопросы в котором сгруппированы в 8 разделов, каждый из которых оценивается в баллах от 0 до 100. Статистические расчёты проведены пакетом Statistica 13. Нормальность распределения данных проверена критерием Шапиро-Уилки и в зависимости от этого критерий Стьюдента или критерий Манна-Уитни были использованы при сравнении различий между группами. Статистически значимым считали $\mathrm{p}<0,05$. Для оценки связи между показателями использовали коэффициент корреляции Спирмена.

Результаты исследований и их обсуждение. При сравнительной оценке результатов качества жизни обоих типов операций было отмечено отсутствие существенных различий через 12 месяцев после операции и выявлена корреляция между снижением индекса массы тела и улучшением показателей качества жизни. Было выявлено, что качество жизни больных морбидным ожирением обеих групп достоверно не отличается. Сравнительные показатели достоверно не отличаются по общей сумме баллов опроса и в отдельных блоках вопросов. Доказана зависимость между снижением массы тела и улучшением качества жизни, улучшается физическая активность при устойчивом снижении индекса массы тела, улучшается социальная жизнь пациентов. Качество жизни пациентов основной группы сопоставима с качеством жизни пациентов после классического шунтирования по Roux-en-Y.
\end{abstract}

Ключевые слова: морбидное ожирение; шунтирование желудка; качество жизни; хирургическое лечение. 